\title{
Cereal Species Effect on Protein Content in Pea Grains in Legume Cereal Mixtures Depending Cropping System
}

\author{
Livija Zarina \\ Institute of Agricultural Resources and \\ Economics, Priekuli \\ Zinatnes 2, Priekuli, LV-4126, Latvia.
}

\author{
Inara Helena Konosonoka \\ Institute of Agricultural Resources and \\ Economics, Priekuli \\ Zinatnes 2, Priekuli, LV-4126, Latvia.
}

\begin{abstract}
Within the European Union's Seventh Framework Programme project "Enhancing of legumes growing in Europe through sustainable cropping for protein supply for food and feed" (EUROLEGUME) producing of the knowledge required for the implementation of legume supported cropping system in sustainable agriculture was done. The main objective of this study was to investigate spring cereal species effect on protein content in pea grains depending cropping system (organic and conventional). The research involved two field pea (Pisum sativum var.arvense L.) cultivars - 'Kirke' and 'Bruno', and two spring cereal species: spring wheat (Triticum aestivum L.) and oat (Avena sativa $\mathrm{L}$.) grown in mixtures.

The results demonstrated that in pea-cereal mixtures cereal species can affect the protein content of grains of pea. Depending cultivar the effect was different. In grains of $\mathrm{cv}$ 'Bruno' crude protein content was highest; the higher the protein of grains fixed in yield from organic field.
\end{abstract}

Keywords - field pea, spring cereals, legume supported cropping system, organic and conventional farming

\section{INTRODUCTION}

Field peas are one of the oldest domesticated crops [21] and are now grown in all world for both human consumption and animal feeding. Peas are high in protein, starch, fiber, and micronutrients [4] and are well adapted to wide range of agroecological conditions, explaining the fact that they are second largest grain legume crop in the world [14]. Not least is the fact that its vines also could be useful as a nitrogen source [22]. Like all legumes, peas are an excellent plant for cropping systems because of its unique ability to fix atmospheric nitrogen [6], [13].

Legumes generally have lower gross margins than cereals, but their rotational effects increase the gross margins of subsequent crops [5]. In addition, legume production can protect and enhance public goods, including through reduced greenhouse gas [11] and nutrient emissions, increased crop and associated biodiversity, and reduced resource requirements of cropping and animal feeding systems [20]. Field pea is invariably grown as a component of a cropping system, and its interaction with other crops is an important consideration in a farmer's decision to grow it [9], [10], [23].

Growing peas in mixtures with cereals is commonly done for forage production because growing of them as sole crops is a challenge since its steam is prone to lodging thereby resulting in harvesting difficulties, reduced yield and decreased profits [2],[15]. However, in Latvia mostly it is thought that growing peas in mixtures with cereals help reduce lodging and weed pressure therefore are grown them in mixtures also for grain [1].

Taking into account that the intercropped legumecereal systems reduce inter-specific competition by enhancing complementary processes thereby improving the exploitation of resources [8], pea-cereal mixtures generally reflecting in the increase of yield of both pea and cereal mixture components. However, previous studies have demonstrated too large effects of climate conditions, so harvests over the years are fluctuating [12], [16], and [24]. Studies have shown that year-on-year fluctuations in pea grain yields in mixtures with cereals are less, particularly in case of organic field [24].

In a temperate climate zone, summer barley, summer wheat and oats are traditionally used for growing peas in mixtures [12], [15], and [16]. In the literature, information is available on the positive effects of peas on the harvest of the supporting plant [7] and, conversely, the impact of the supporting plant on the quality of pea yields is very limited in the results of the studies [17].

On the basis of fact that one of the essential factors determining the quality of yield is genotype [19], as well as the fact that quality, i.e., chemical composition, is also affected by farming systems [3], the main objective of this study was to investigate spring cereal species effect on protein content in two maturity classes pea cultivars grains depending cropping system (organic and conventional). 


\section{MATERIALS AND METHODS}

Site and soil description. Three years experiments were performed in organically and conventionally managed sod podzolic loamy sandy soil fields at the Priekuli Researc Centre of the Institute of Agricultural Resources and Economics during 2014-2016. A measurement of basic soil agrochemical characteristics $(\mathrm{pH}$, organic matter, available phosphorus and potassium) was performed every year accordingly corresponding methodology traditionally adopted for agricultural experimental fields: pHKCL- LVSISO10390: 2006, organic matter content (according to Tyurin method) - LVSTZM80-91), phosphorus and potassium content (by Egner-Rhym method) - LVSTZM82-97, and are presented in Table 1.

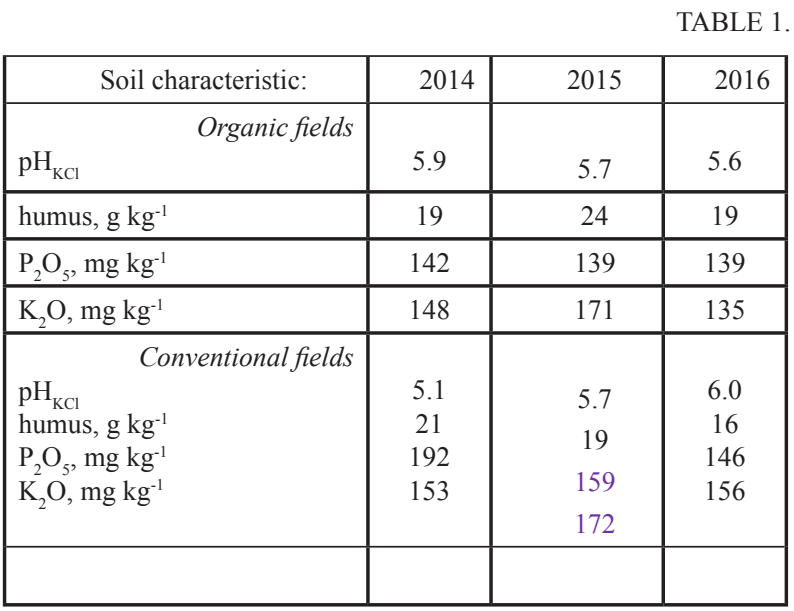

SOIL CHARACTERISTICS OF EXPERIMENTAL FIELDS

\section{Field and crop management}

In organic farming system field the field crops have been cultivated according to the principles of organic farming since 2003. Pea - cereal mixtures were grown in six-field crop rotation: spring barley with red clover as undersown - red clover - spring cereals - winter rye - potatoes - pulses. In conventional farming system field the sequence of crops was as follows: spring cereals with white clover as undersown - white clover for seed production (three years using) - winter cereals - potatoes - pulses.

Soil tillage technology in crop rotation was based on the traditional manners-the mouldboard ploughing to a depth of $20 \mathrm{~cm}$ in autumn and cultivations (twice) before sowing in spring. Straw and crop residues were crushed in pieces of $5-7 \mathrm{~cm}$ pieces and dispersed. In organic field weeds were controlled in the spring cereals and pulses after sowing and in the rye field at the end of April or in the beginning of May by spring-tine harrowing. In the potato field inter-rows $(70 \mathrm{~cm}$ spacing) were harrowed and cultivated three to four times, respectively. In conventional field pesticides were used: insecticidedeltametrin, herbicide- bentason and pendimetalin).

As the basic soil fertility management measure for organic field was green manure (crucifers or buckwheat), for conventional field - mineral fertilizers using doses according to soil analyses. Additionally the enriching of soil was achieved by cultivating of clover as the improvement through the nitrogen fixation, as well as by turning the plants residues into the soil.
Sowing of mixtures (with Hege) was performed in last decade of April, using sowing rate 60 seeds $\mathrm{m}^{2}$ of pea kernels for mixtures and 120 seeds $\mathrm{m}^{2}$ for pure stand of pea. Grain yield of the plots was harvested at complete maturity stage with combine Sampo till the middle of August, dried and the yield data (determined moisture content of $14 \%$ ) recorded for each plot and finally calculated for $\mathrm{tha}^{-1}$.

\section{Weather conditions}

The data about air temperature and rainfall were obtained from the Priekuli observation station which shows that weather conditions during research period were different, and are presented in table 2 and 3.

TABLE 2.

\begin{tabular}{lcccc}
\hline $\begin{array}{c}\text { Mean air tem- } \\
\text { perature, }{ }^{0} \mathrm{C}\end{array}$ & 2014 & 2015 & 2016 & $\begin{array}{c}\text { Long term } \\
\text { average }\end{array}$ \\
\hline April & 7.1 & 5.4 & 6.1 & 4.8 \\
May & 11.9 & 10.2 & 14.5 & 11.1 \\
June & 13.5 & 14.3 & 16.4 & 14.8 \\
July & 19.5 & 15.9 & 17.9 & 16.9 \\
August & 16.7 & 17.8 & 16.3 & 15.9 \\
September & 12.2 & 12.9 & 12.9 & 12.1 \\
\cline { 2 - 5 } & \multicolumn{3}{|l}{} \\
\cline { 2 - 5 } & & &
\end{tabular}

TEMPERATURE DURING GROWING PERIOD

TABLE 3.

\begin{tabular}{|l|c|c|c|c|}
\hline $\begin{array}{c}\text { Precipitation per } \\
\text { month, mm }\end{array}$ & 2014 & 2015 & 2016 & $\begin{array}{c}\text { Long term } \\
\text { average }\end{array}$ \\
\hline April & 32.1 & 75.8 & 82.2 & 39.6 \\
\hline May & 96.7 & 53.3 & 9.8 & 55.9 \\
\hline June & 108.3 & 39.4 & 144.5 & 78.5 \\
\hline July & 76.5 & 91.5 & 109.5 & 93.3 \\
August & 158.2 & 24.1 & 175.8 & 87.9 \\
September & 30 & 42.1 & 23.2 & 65.3 \\
\hline & & & & \\
\hline
\end{tabular}

MOISTURE DURING GROWING PERIODGenotypes,

\section{Measuring and sampling}

The varieties of field pea were: 'Bruno'- pink flowered, semi- leafless, medium early maturity variety, bred in Latvia and Estonian variety 'Kirke'- pink flowered, early maturity and with good résistance to diseases. Varieties of other mixture components were: 'Laima' (oat) - characterized by high and stable grain yield under different climatic conditions, have high resistence to diseases. 'Uffo' (spring wheat) - mid-early, having high yield potential, characterized by moderate lodging resistance. The grain quality is suitable for food and feed.

Evaluation of phenology of crops by recording of dates of the beginning of emergence (when at least $50 \%$ of cotydelons were opened) and beginning of flowering (when at least 50\% of flowers were opened) was carried out. For measurements 10 plants per plot were selected. Plant high was measured at the beginning of flowering (BBCH 61-64) and at the beginning of forming pods (BBCH 71-75) and at the beginning of maturity (BBCH 81-85). Amount of pods per plant also were counted.

Pea seed samples were analysed on protein content in the four replications $(\mathrm{n}=4)$ by near infrared spectroscopy by using an XDS Rapid Analyzer (Foss) where the average sample of all 
applications was analysed for each variant.

\section{Statistical analysis}

Data were subjected to analyses of variance (ANOVA) using STATISTICA. The level of significance was set at $\mathrm{p}<0.05$.

\section{RESULTS AND DISCUSSION}

Plant development and the yield

The plants in the organic field were taller, more podded, that ultimately led to higher yields (Table 4). Similar Kadžiuliene et all, 2010 [12], we found that number of the productive steams was lower in the mixture crops than in sole peas. Number of pods also was lower.

\begin{tabular}{|l|c|c|c|}
\hline \multicolumn{1}{|c|}{$\begin{array}{c}\text { Variety } \\
\begin{array}{l}\text { Plant hight in the } \\
\text { beginning of } \\
\text { flowering, cm }\end{array}\end{array}$} & $\begin{array}{c}\text { Amount of } \\
\text { pods per plant }\end{array}$ & $\begin{array}{c}\text { Yield of pea, } \\
\text { tha }^{-1}\end{array}$ \\
\hline Conventional field & \multicolumn{3}{|c|}{} \\
\hline Kirke+oat & $51 \mathrm{c}$ & $2 \mathrm{c}$ & $0,36 \mathrm{c}$ \\
\hline Kirke+wheat & $54 \mathrm{c}$ & $3 \mathrm{~b}$ & $0,35 \mathrm{c}$ \\
\hline Kirke, sole & $51 \mathrm{c}$ & $4 \mathrm{a}$ & $1,14 \mathrm{ab}$ \\
\hline Bruno+oat & $64 \mathrm{~b}$ & $2 \mathrm{c}$ & $0,58 \mathrm{bc}$ \\
\hline Bruno+wheat & $68 \mathrm{ab}$ & $2 \mathrm{c}$ & $0,62 \mathrm{~b}$ \\
\hline Bruno, sole & $73 \mathrm{a}$ & $4 \mathrm{a}$ & $1,61 \mathrm{a}$ \\
\hline $\begin{array}{l}\text { ANOVA }, \\
\text { p-value }\end{array}$ & 3,2 & 0,9 & 0,88 \\
\hline Organic field & & & \\
\hline Kirke+oat & $68 \mathrm{c}$ & $6 \mathrm{~b}$ & $1,19 \mathrm{~b}$ \\
\hline Kirke+wheat & $68 \mathrm{c}$ & $6 \mathrm{~b}$ & $1,11 \mathrm{~b}$ \\
\hline Kirke, sole & $85 \mathrm{a}$ & $8 \mathrm{a}$ & $3,91 \mathrm{a}$ \\
\hline Bruno+oat & $81 \mathrm{~b}$ & $5 \mathrm{c}$ & $0,85 \mathrm{c}$ \\
\hline Bruno+wheat & $86 \mathrm{a}$ & $6 \mathrm{~b}$ & $1,50 \mathrm{~b}$ \\
\hline Bruno, sole & $87 \mathrm{a}$ & $8 \mathrm{a}$ & $3,27 \mathrm{a}$ \\
\hline ANOVA \\
p-value
\end{tabular}

PLANT DEVELOPMENT AND THE YIED OF PEA IN MIXTURES

Compared to years in 2014 a slight increase in the plant length was fixed that can be explained by the abundance of precipitation at the beginning of vegetation. There were no differences found between the plant length, amount of pods and yield level of pea 'Kirke' from plots with mixtures in organic field. Significantly higher yield was obtained from both mid-early maturity 'Kirke' and mid-late maturity 'Bruno' sole plots. This fact leads to the conclusion that the tested varieties in mixtures form lower yields than pure ones, irrespective of the farming system.

Within experimental period the higher yield was obtained in 2015 when July was characterized by moderate monthly temperature $\left(15.9^{\circ} \mathrm{C}\right)$ and rainfall $(91.5 \mathrm{~mm})$, followed by relatively dry and warm August [25]. The results showed that the productivity of pea in mixtures not depended on the species of cereals but there was high dependence on cultivation conditions. Differences seem to be related to the better organic performance- an organically managed field provides necessary conditions for yield formatting also in adverse climate conditions.
However, this is only an assumption, because the trials were carried out in fields with different plant sequences.

\section{Protein content}

Data (Fig. 1 and Fig.2) indicate the effect of genotype on protein content in grains, regardless of the farming system. The highest yield was obtained in 'Bruno'- from 23.5 to $24.7 \%$ in conventional field and from 23.9 to $27.8 \%$ in organic field, which is more than 2.9 and $2.8 \%$ than the other variety, accordingly. Variety 'Bruno' also has shown high protein content in other studies [19].

In the case of cultivations of pea in mixtures, less impact was fixed on the organic field. In the conventionally managed field, the protein content of pea grain from sole plots was higher in all experimental years than in mixtures, while in organically managed field these differences were not significant.

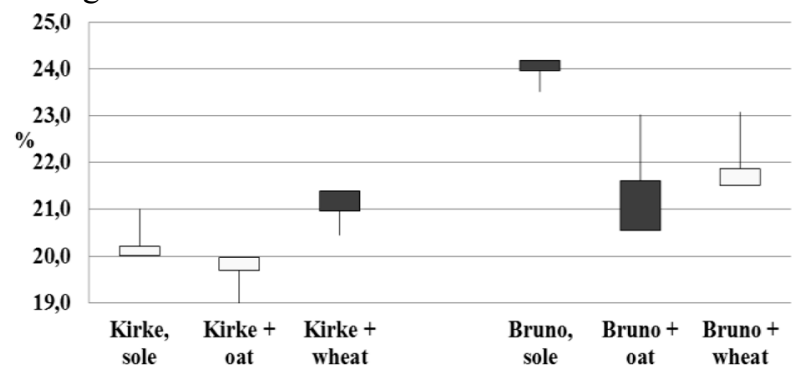

Fig. 1. Protein content in pea grains from conventional field

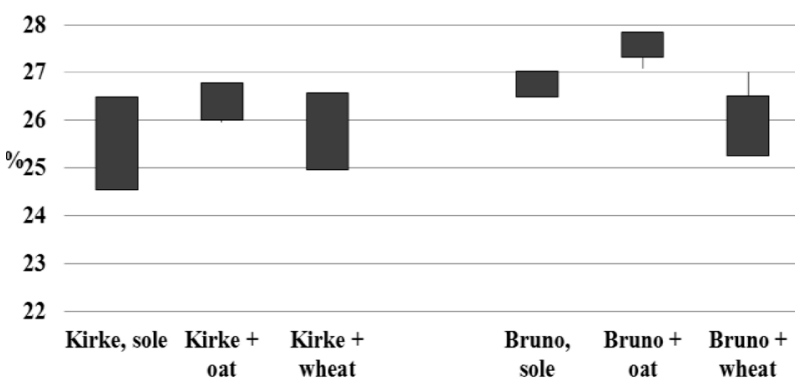

Fig. 2.

Protein content in pea grains from organic field

The yield of crude protein in the mixtures varied between experimental years, suggesting the sensitivity of peas to agroecological factors which are already known from other [16] research results. However, the results of our studies show that choice of cereal species (spring wheat or oat) for mixture does not affect or affect insignificant the protein content in pea grains. Taking into account that through growing of legume-cereal mixtures enriched feed, it was important to clear also other relationships between mixture crops.

\section{CONClusion}

The choice of spring cereal species for pea-cereal mixtures does not affect the protein content of pea cultivar's 'Kirke' and 'Bruno' grains.

The maximum protein yield per area unit was obtained from plots of pure crops. In a mix with cereals pea yield decreased.

The effect of the farming system on the protein content of pea grains was fixed: in the conventional field, compared to organic, the difference between the 
protein content of sole sown plots and mixtures was more pronounced.

\section{ACKNOWLEDGMENTS}

This work was supported by the European Commission within the FP7 research project 'EUROLEGUME Enhancing of legumes growing in Europe through sustainable cropping for protein supply for food and feed (grant agreement no 613781)'.

\section{REFERENCES}

[1] L.Agafonova, A. Jansons, S. Rancāne. "Efficiency of cultivation of cereal - papilionaceous mixtures in organic farming conditions", in Proceedings of the 7th International Scientific and Practical Conference: Environment. Technology. Resources, Rezekne, RA izdevniecība, 2009, pp. 107-112.

[2] A. Auskalnis, "Influence of sowing depth on productivity of peas on sandy loam soil" (in Lithuanian with English abstract). Zemdirbyste-Agriculture, 2001, pp.74-105.

[3] L. Bedoussac, E.P. Journet, H. Hauggaard-Nielsen, C. Naudin, G. Corre-Hellou, E.S. Jensen, L. Prieur, E. Justes. "Ecological principles underlying the increase of productivity achieved by cereal-grain legume intercrops in organic farming". A review. Agronomy for Sustainable Development, July 2015, Volume 35, Issue 3, pp. 911-935.

[4] J.I. Boye, Z. Ma. "Impact of Processing on Bioactive Compounds of Field Peas" in: Processing and Impact on Active Components in Food, 2015, pp. 63-70.

[5] C. Cernay, E. Pelzer, D.A.Makowski. "A global experimental dataset for assessing grain legume production”. Sci. Data 3, 2016, 160084.

[6] T.E. Crews, M.B. Peoples. "Legume versus fertilizer sources of nitrogen: ecological tradeoffs and human needs".

Agric. Ecosyst. Environ. 2004, pp. 279-297.

[7] G. Corre-Hellou, J. Fustec, Y. Crozat. "Interspecific competition for soil $\mathrm{N}$ and its interactions with $\mathrm{N} 2$ fixation, leaf expansion and crop growth in pea-barley intercrops", Plant Soil 282, 2006, pp.195-208.

[8] O. Duchene, J.F. Vian, F. Celette. "Intercropping with legume for agroecological cropping systems: Complementarity and facilitation processes and the importance of soil microorganisms". A review. Agriculture, Ecosystems \& Environment.Volume 240, 1 March 2017, pp. 148-161.

[9] G. Due, J.M. Aleksic, A. Mikic, J. Paull, R.J. Redden, O. Sass, F.L. Stoddard, A.Vandenberg, M.Vishnyakova, A.M. Torres. "Grain legumes", De Ron, A.M (ed.). Handbook of Plant Breeding 10, Springler Science+Business Media New Yourk, 2015, pp. 141-178.

[10]I. Huňady, M. Hochman. "Potential of legume-cereal intercropping for increasing yields and yield stability for self-sufficiency with animal fodder in organic farming". Czech Journal of Genetics and Plant Breeding, 2014, 50(2), pp. 185-194.

[11]E.S. Jensen, M.B. Peoples,R.M. Boddey, P.M. Gresshoff, H. Hauggaard-Nielsen, B.J.R. Alves, M.J. Morrison. "Legumes for mitigation of climate change and the provision of feedstock for biofuels and biorefineries: a review". Agron Sustainable Dev 2011, V.32, pp. 329-364.
[12]Ž. Kadžiulienè, L. Šarūnaitè, I. Deveikytè. "Effect of Pea and Spring Cereals Intercropping on Grain Yield and Crude Protein Content". Ratar. Povrt. / Field Veg. Crop Res. 48, 2011, pp.183188.

[13]A. Karkanis, G. Ntatsi, C.K.Kontopoulou, A. Pristeri, D. Bilalis, D.Savvas. "Field Pea in European Cropping Systems: Adaptability, BiologicalNitrogen Fixation and Cultivation Practices". Not Bot Horti Agrobo, 2016, 44(2), pp. 325-336.

[14] T.N. Khan, J.S. Croser. "Encyclopedia of Grain Science", 2004.

[15]M. Kontturi, A. Laine, M. Niskanen, T. Hurme, M. Hyövelä, P. Peltonen-Sainio. "Pea-oat intercrops to sustain lodging resistance and yield formation in northern European conditions". Acta Agriculturae Scandinavica, Section B - Soil \& Plant Science Volume 61, 2011, Issue 7, pp. 612-621.

[16]R. Lauk, E. Lauk. "Pea-oat intercrops are superior to pea-wheat and pea-barley intercrops". Acta Agric. Scand. Section B: Plant Soil Sci. 2008, 58, pp. 139-144.

[17]E. Malezieux, Y. Crozat, C. Dupraz, M. Laurans, D. Makowski, H. Ozier-Lafontane, B. Rapidel, S.de Tourdonnet, V.M. Morison. "Mixing plant species in cropping systems: concepts, tools and models". A review. Agron. Sustain. Dev. 29, pp. 43-62.

[18]R.W. Neugschwandtner, H.P. Kaul. "Concentrations and uptake of macronutrients by oat and pea in intercrops in response to $\mathrm{N}$ fertilization and sowing ratio". Archives of Agronomy and Soil Science Volume 62, 2016 - Issue 9

[19]M. Olle. "The yield, height and content of protein of field peas (Pisum sativum L.) in Estonian agro-climatic conditions". Agronomy Research 2017, Vol. 15, No. 4.

[20] S. Preissel, M. Reckling, J. Bachinger, P. Zander. "Introducing Legumes into European Cropping Systems: Farm-level Economic Effects" CAB International 2017. Legumes in Cropping Systems (eds D. Murphy-Bokern, F.L. Stoddard and C.A. Watson), pp.209225 .

[21]P. Smýkal, G. Aubert, J. Burstin, J. Clarice, G.J.Coyne, N.T.H.Ellis, A.J.Flavell, R. Ford, M. Hýbl, J. Macas, P. Neumann, K.E. McPhee, R.J. Redden, D. Rubiales, J.L. Weller,and T.D. Warkentin. "Pea (Pisum sativum L.) in the Genomic Era". Review Agronomy, 2012, 2(2), pp. 74-115.

[22]L. Tripolskaja, D. Romanovskaja, A. Slepetiene. "The effect of various soil and crop management practices on the humus status in sandy loam Haplic Luvisol" (in Lithuanian with English abstract). Zemdirbyste-Agriculture, 95, pp. 3-18.

[23]P. Zander, T.S. Amjath-Babu, S.Preissel, M. Reckling, A. Bues, N. Schläfke, T. Kuhlman, J. Bachinger, S. Uthes, F. Stoddard, D. Murphy-Bokern, C.Watson. "Grain legume decline and potential recovery in European agriculture: a review”. Agron. Sustain. Dev., 2016, pp. 36:26.

[24] L. Zarina, I. Alekse. "The yield of legume-cereal mixtures depending supporting crop and sowing rate in Vidzeme agroecological conditions". Proceedings of the Scientific and Practical Conference Harmonious Agriculture, 25.- 26.02.2016., LLU, Jelgava, Latvija, pp. 219-220, (in Latvian with English abstract).

[25]L. Zarina, I, Alsina, A.Vaivode.”Effectiveness of Rhizobial Strains on the Faba Bean Development and Yield in Soddy

Podzolic Soils", Environment. Technology. Resources, 2017, Volume I, pp. 305-308. 